\title{
Evaluating the virulence of Metarhizium anisopliae (Deuteromycotina: Hyphomycetes) and Beauveria bassiana (Ascomycota: Hypocreales) isolates to Arabian rhinoceros beetle, Oryctes agamemnon arabicus
}

\author{
M.W. Khudhair, M.Z. Khalaf, H.F. Alrubeai, A.K. Shbar, B.S. Hamad, H.S. Khalaf \\ Integrated Pest Control Research Center, Agricultural Research Directorate, Ministry of Science \\ and Technology, Baghdad, Iraq
}

\begin{abstract}
Virulence of entomopathogenic fungi Metarhizium anisopliae and Beauveria bassiana were tested against Arabian Rhinoceros Beetle, Oryctes agamemnon arabicus larvae. Four concentrations $\left(1 \times 10^{5}\right.$, $1 \times 10^{7}, 1 \times 10^{9}$ and $1 \times 10^{11}$ conidia/mL $\mathrm{m}^{-1}$ ) of two locally isolated entomopathogenic fungi spore suspensions were used in this study via larval direct spraying. Results revealed that both isolates can cause high mortality rate reaching $100 \%$ after 29 days. However, Beauveria bassiana scored higher mortality rate in short time especially at the concentration of $1 \times 10^{11}$ conidia/ $\mathrm{mL}^{-1}$ with lethal time (LT) ${ }_{50} 12.75$ and $\mathrm{LT}_{90}$ 20.00; while, Metarhizium anisopliae caused the higher percentage of malformed adults. Moreover, both isolates affected insect's life cycle particularly in the pupal stage which was reduced remarkably by almost $50 \%$ in comparison with the control treatment.
\end{abstract}

Correspondence: Mohammed W. Khudhair, Integrated Pest Control Research Center, Agricultural Research Directorate, Ministry of Science and Technology, Baghdad, Iraq.

E-mail: mohammedwaleed74@yahoo.com ;

mohammed.khudhair@uqconnect.edu.au

Key words: Biological control; date palm borer; Mycoinsecticide; Metarhizium anisopliae; Beauveria bassiana.

Acknowledgements: the authors acknowledge the all different support by the administration of Agricultural Research Directorate-Iraqi Ministry of Science and Technology and the IPM Center. Acknowledgment also express to Rassoul Ali, Omar Mohammed, Nadia Jassim, and Bushra Hamza, for their assistance.

Received for publication: 27 March 2015.

Revision received: 30 September 2015.

Accepted for publication: 30 September 2015.

(C) Copyright M.W. Khudhair et al., 2015

Licensee PAGEPress, Italy

Journal of Entomological and Acarological Research 2015; 47:5180

doi:10.4081/jear.2015.5180

This article is distributed under the terms of the Creative Commons Attribution Noncommercial License (by-nc 3.0) which permits any noncommercial use, distribution, and reproduction in any medium, provided the original author(s) and source are credited.

\section{Introduction}

Date palms, Phoenix dactylifera L. are most economically important fruit trees in tropical and subtropical areas and are grown throughout large area spanning many countries including Iraq (Abdullah et al., 2010; Abul-Soad et al., 2011). One of the most important pests that infests date palm trees in Iraq and many other countries such as Iran, Saudi Arabia, Oman, Egypt, Tunisia, Libya and Qatar is palm tree borer that belongs to different species of genus Oryctes such as 0 . agamemnon, and 0 . elegans (Hussain, 1974; Dhiab et al., 1979; Bedford, 1980; F.A.0., 1982; Elwan \& Al-Tameimi, 1999; Soltani, 2010). Oryctes species larvae can cause high yield losses, destroying trees and seedlings in oil palm, date palm, and coconut palm (Ragoussis et al., 2007; Al-Deeb et al., 2012). Borers and their larvae develop special breeding sites (tunnels) inside different plant parts such as root, stem, and crown making their control very difficult (Soltani, 2012). Rochat et al. (2004) mentioned that Arabian rhinoceros beetle causes direct and indirect damages exemplified by infesting young trees especially on apical bud providing eligible environment for secondary invaders. Controlling date palm borers byusing insecticides is not efficient because borers spend long time hiding inside their feeding and breeding sites (Ragoussis et al., 2007), making their control very difficult. Moreover, most of the employed insecticides are contaminant dangerous to both people and ecosystem.

The entomopathogenic fungi Metarhizium anisopliae (Deuteromycotina: Hyphomycetes) and Beauveria bassiana (Ascomycota: Hypocreales) were used to control many arthropods pests such as beetles, aphids, plant hoppers, pear psylla, and termites (Milner \& Soper, 1981; Liu et al., 1989; Samuels et al., 1989; Moorhouse et al., 1993; Puterka et al., 1994). They were tested against red palm weevil Rhynchophorus ferrugineus (Olivier) revealing high mortality rate among larvae reaching 100\% after 6-7 days of treatment; moreover, treated eggs expressed lower hatching percentages (Gindin et al., 2006). M. anisopliae expressed high virulence against sugarbeet root maggot larvae as reported by Jonason $e t$ al. (2005). They were also applied to control brown-winged green bug, Plautia stali Scotto (Hemiptera: Pentatomidae) revealing efficient and successful outcome (Ihara et al., 2001).

In this investigation laboratory bioassays were conducted using four spore suspension concentrations $\left(1 \times 10^{5}, 1 \times 10^{7}, 1 \times 10^{9}\right.$, and $\left.1 \times 10^{11}\right)$ of the isolates $M$. anisopliae and $B$. bassiana that were isolated from Iraqi environment to evaluate their ability to control 0 . agamemnon arabicus larvae.

\section{Materials and methods}

Two locally isolated entomopathogenic fungi were used in this study: MARD 34 and 46 (Table 1); selected from Entomopathogenic 
Fungal Isolates Bank at the Agricultural Research Directorate, Iraqi Ministry of Science and Technology.

\section{Fungal isolation and purification}

Entomopathogenic fungi B. bassiana (MARD46) was isolated using bait trap method (Zimmermann, 1986) with wax moth Galleria mellonella L. larvae. Soil samples were collected from 42 sites and from specific points according to global positioning system during two seasons of (2012 and 2013) and 31\% of the collected samples expressed entomopathogenic fungi. Over 94 isolates were collected from the examined soil sources and sites. Results revealed that $75.5 \%$ of the isolated entomopathogenic fungi were Beauveria bassiana and 18.1\% were Metarhizium anisopliae followed by Lecanicillium lecanii with $4.3 \%$, Paecilomyces lilacinus and Fusarium sp. recorded the lowest frequency among other species with $1.1 \%$ as illustrated in Table 2 (Khudhair et $a l ., 2014)$. Soil samples were sieved to remove roots and big solid materials; then $40 \mathrm{~g}$ of soil was placed into plastic petri dish. Fourth instar G. mellonella larvae (5-6) were released in each petri dish followed by sealing them with parafilm and three replicates from each sample were used. Dishes were incubated in the dark at $25 \pm 2{ }^{\circ} \mathrm{C}$ and $70 \%$ relative humidity (RH) for two weeks. Observations were taken every three days, and dead larvae were removed, washed with tap water and placed in a new sterile petri dish on a filter paper that wetted with sterile distilled water providing high level of humidity. Dishes were incubated in the dark to allow fungal mycelia to grow over dead larvae. M. anisopliae (MARD34) isolate was collected from infected date palm borer adult that revealed fungal growth. Fungal isolate was sub-cultured many times on full strength potato dextrose agar (PDA) medium. Strains were purified onto quarter-strength PDA plates which contain $100 \mu \mathrm{g}$ streptomycin sulphate and $10 \mu \mathrm{g}$ tetracycline hydrochloride $\mathrm{mL}^{-1}$. Plates were incubated at room temperature and placed in the dark for 5 -7 days.

Single monoconidial strains selection was done via making local spore suspension by adding 3-4 drops of sterile distilled water on the fungal colony that were grown on the plate using flame-sterilised loop. Spore suspension was streaked onto $2 \%$ water agar media by using a flame-sterilised metal loop and plates were incubated under laboratory conditions for $24 \mathrm{~h}$. A single germinated spore was transferred onto full-strength PDA media plate and incubated at ambient temperature according to Scott and Chakraborty (2010).

Recovered isolates were retested against $G$. mellonella larvae using 3 replicates each replicate contains 10 larvae with three spore suspension concentrations: $1 \times 10^{5}, 1 \times 10^{7}$, and $1 \times 10^{9}$. The highest mortality rate was expressed by the two selected isolates in this study (MARD 34 and 46 ) reaching over $70 \%$ encouraged using them against 0 . agamemnon arabicus.

\section{Borer culture}

Borer larvae of 0 . agamemnon arabicus were collected from severely infested date palm trees from February to April 2014. Trees were cut into small pieces and early stages of larvae were collected from tunnels and kept in special plastic cages $30 \times 20 \times 22.5 \mathrm{~cm}$. Larvae were reared at $25 \pm 2^{\circ} \mathrm{C}$ and $30 \% \mathrm{RH}$ and fed on small pieces $(5 \times 10 \mathrm{~cm})$ bunch stalks. Fresh stalk pieces were added regularly every two weeks to keep enough fresh food to the larvae. Larvae were kept until reaching the last larval instar for treatment, and then used for different treatments.

\section{Bioassay test}

Spore suspension was prepared by adding $5 \mathrm{~mL}$ of sterile distilled water to well developed colonies growth isolate Petri dish; then, by using a sterile metal scraper, fungal mycelia were scraped and the suspension was poured into a $50 \mathrm{~mL}$ Falcon tube after filtering the suspension through sterile miracloth (Billerica, MA, USA). The spore concen- tration was determined using haemocytometer and adjusted to $1 \times 10^{5}$, $1 \times 10^{7}, 1 \times 10^{9}$ and $1 \times 10^{11}$ conidia/ $\mathrm{mL}^{-1}$. The four concentrations were applied separately by direct spraying on the larvae and their food. Three replicates (5 larvae each) were used for each treatment. Borer larvae in each replica were transferred into new sterilised cage $30 \times 20 \times 22.5$ $\mathrm{cm}$. The top of each cage was covered by cloth for ventilation and reducing humidity. Controls were sprayed with sterile distilled water only. Cages were kept under rearing room conditions $25 \pm 2{ }^{\circ} \mathrm{C}$ and $70 \% \mathrm{RH}$ and they were checked every three days to count dead larvae monitor their behaviour, and any noticeable morphological changes.

\section{Statistical analysis}

Probit analysis was used to determine the mean lethal time $\left(\mathrm{LT}_{50}\right)$. Mortality was transformed to arcsine transformation; then, data were subjected to analysis of variance using SPSS V. 20. Means were separated by using Duncan's multiple range tests.

\section{Results}

Survival percentages of date palm larvae after treating them with entomopathogenic fungal isolate MARD 46 spore suspensions revealed that the concentration $1 \times 10^{11}$ inflict the highest mortality among larvae reaching $93.33 \%$ after 19 days $\left(\mathrm{LT}_{50}=12.67\right.$ and $\mathrm{LT}_{90}=20.00$, Figure 1$)$, followed by the concentration $1 \times 10^{9}$ that recorded mortality of $66.66 \%$ at the same time (Figure 1). In addition, mortality reached $53.33 \%$ after 19 days using concentration of $1 \times 10^{7}$ and the lowest mortality was $40 \%$ at the concentration $1 \times 10^{5}$ after 19 days. All concentrations used decreased larval survivals with time progression reaching $0.0 \%$ at the end of the experiment (29 days) (Figure 1).

Figure 2 illustrates survival percentages of date palm borers' larvae during experiment duration (29 days) treated with different spore suspension concentrations of $M$. anisopliae (MARD 34). The results revealed that the highest mortality after 19 days was $66.66 \%$ at the concentration $1 \times 10^{11}$ followed by the concentration $1 \times 10^{9}$ with $53.33 \%$ at the same time. The lowest mortality scored at the concentrations $1 \times 10^{5}$ and $1 \times 10^{7}$ reaching $46.66 \%$ after 19 days of the treatment. All concentration recorded decreased survival with time, reaching $0 \%$ at the end of the experiment (Figure 2).

Comparison between survival percentages results of different concentrations of the two used isolates MARD 34 and MARD 46 revealed that there were no significant differences (44.66 and 40\%) between them at the lowest concentration. However, there was a significant dif-

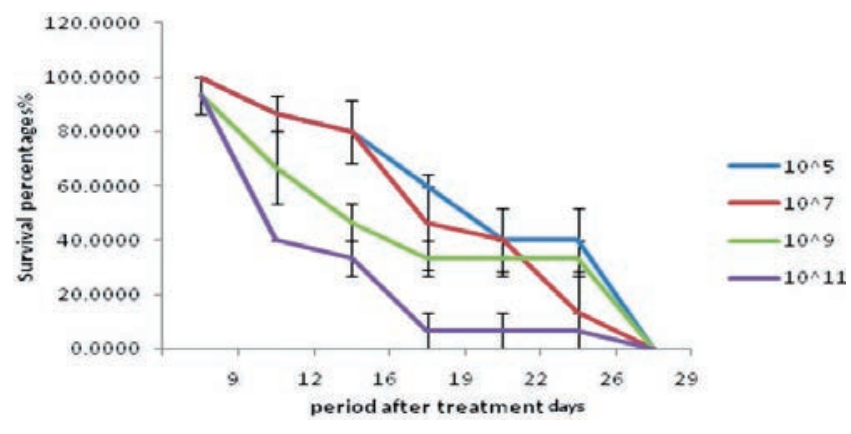

Figure 1. Survival percentages and error bar among date palm borer larvae $O$. agamemnon arabicus treated with the $B$. bassiana isolate MARD46 four spore suspension concentrations. 
ference between the two isolates at the concentration $1 \times 10^{11}$ especially the isolate MARD 46 which scored higher and faster survival reduction after 19 days in comparison with the isolate MARD 34.

Adults' malformations especially in the wings (number and degree) were recorded in almost all concentrations after 20 days of treatment
(Table 3 and Figure 3). The highest malformed adults' number and degree of malformation were recorded at the concentration $1 \times 10^{11}$ of the isolates MARD 34 especially after 27 days of treatment (Table 3); while, the lowest malformed adults' number and degree was recorded at the concentration $1 \times 10^{11}$ of MARD 46 especially after 27 days of treatment.

Table 1. Isolates of M. anisopliae and B. bassiana.

\begin{tabular}{|c|c|c|c|c|c|}
\hline Isolate code & Species & Location & Longitude & Latitude & Isolation source \\
\hline MARD 34 & Metarhizium anisopliae & Basrah Province & $47^{\circ} 77^{\prime}$ East & $30^{\circ} 68^{\prime}$ North & $\begin{array}{l}\text { Infected adult } \\
\text { of } 0 \text {. agamemnon arabicus } \\
\text { Date palm and Citrus orchard }\end{array}$ \\
\hline MARD 46 & Beauveria bassiana & $\begin{array}{c}\text { Dhi Qar Province } \\
\text { Nasrea city }\end{array}$ & $46^{\circ} 48^{\prime}$ East & $31^{\circ} 13^{\prime}$ North & Date palm, orchard soil \\
\hline
\end{tabular}

Table 2. Sites of soil sources.

\begin{tabular}{|c|c|c|c|c|c|}
\hline Province & Site & Locations & Longitude & Latitude & Soil source \\
\hline Baghdad & $\begin{array}{l}\text { Tarmia } \\
\text { Youssoufia } \\
\text { Kweresh } \\
\text { Khamisah } \\
\text { Mahmoudia } \\
\text { Al-Mada'in } \\
\text { Sakhrijah } \\
\text { Abu Ghraib } \\
\text { Tuwaitha }\end{array}$ & $\begin{array}{l}3 \\
3 \\
1 \\
2 \\
3 \\
3 \\
1 \\
3 \\
1\end{array}$ & $\begin{array}{l}44^{\circ} 25^{\prime} \mathrm{E} \\
44^{\circ} 43^{\prime} \mathrm{E} \\
44^{\circ} 42^{\prime} \mathrm{E} \\
44^{\circ} 39^{\prime} \mathrm{E} \\
44^{\circ} 39^{\prime} \mathrm{E} \\
44^{\circ} 56^{\prime} \mathrm{E} \\
44^{\circ} 39^{\prime} \mathrm{E} \\
44^{\circ} 30^{\prime} \mathrm{E} \\
44^{\circ} 30^{\prime} \mathrm{E}\end{array}$ & $\begin{array}{l}33^{\circ} 64^{\prime} \mathrm{N} \\
33^{\circ} 14^{\prime} \mathrm{N} \\
33^{\circ} 14^{\prime} \mathrm{N} \\
33^{\circ} 11^{\prime} \mathrm{N} \\
33^{\circ} 11^{\prime} \mathrm{N} \\
33^{\circ} 15^{\prime} \mathrm{N} \\
33^{\circ} 09^{\prime} \mathrm{N} \\
33^{\circ} 17^{\prime} \mathrm{N} \\
33^{\circ} 12^{\prime} \mathrm{N}\end{array}$ & $\begin{array}{c}\text { Date palm } \\
\text { Date palm } \\
\text { Date palm } \\
\text { Date palm + Citrus } \\
\text { Date palm + Citrus } \\
\text { Date palm + Citrus } \\
\text { Date palm + Citrus } \\
\text { Trefoil fields } \\
\text { Sesame fields }\end{array}$ \\
\hline Wasit & $\begin{array}{c}\text { Suwayrah } \\
\text { Aziziya } \\
\text { Al-Numaniyah } \\
\text { Al-Hafriyah } \\
\text { Kut } \\
\text { Dabuni } \\
\text { Shethaif-Al Garbie } \\
\text { Brinaga } \\
\text { Al Zubaidiya }\end{array}$ & $\begin{array}{l}3 \\
4 \\
4 \\
1 \\
3 \\
1 \\
3 \\
3 \\
3\end{array}$ & $\begin{array}{l}44^{\circ} 49^{\prime} \mathrm{E} \\
45^{\circ} 06^{\prime} \mathrm{E} \\
45^{\circ} 24^{\prime} \mathrm{E} \\
44^{\circ} 84^{\prime} \mathrm{E} \\
45^{\circ} 49^{\prime} \mathrm{E} \\
45^{\circ} 21^{\prime} \mathrm{E} \\
45^{\circ} 11^{\prime} \mathrm{E} \\
45^{\circ} 05^{\prime} \mathrm{E} \\
45^{\circ} 40^{\prime} \mathrm{E}\end{array}$ & $\begin{array}{l}33^{\circ} 23^{\prime} \mathrm{N} \\
32^{\circ} 90^{\prime} \mathrm{N} \\
32^{\circ} 35^{\prime} \mathrm{N} \\
32^{\circ} 99^{\prime} \mathrm{N} \\
32^{\circ} 30^{\prime} \mathrm{N} \\
32^{\circ} 21^{\prime} \mathrm{N} \\
32^{\circ} 87^{\prime} \mathrm{N} \\
32^{\circ} 89^{\prime} \mathrm{N} \\
32^{\circ} 31^{\prime} \mathrm{N}\end{array}$ & $\begin{array}{c}\text { Date palm + Citrus } \\
\text { Date palm + Citrus } \\
\text { Date palm + Citrus } \\
\text { Date palm + Citrus } \\
\text { Date palm + Citrus } \\
\text { Wheat field } \\
\text { Date palm } \\
\text { Date palm + Citrus } \\
\text { Date palm + Citrus }\end{array}$ \\
\hline Diyala & $\begin{array}{c}\text { Diyala } \\
\text { Al Khalis }\end{array}$ & $\begin{array}{l}2 \\
1\end{array}$ & $\begin{array}{l}44^{\circ} 42^{\prime} \mathrm{E} \\
44^{\circ} 56^{\prime} \mathrm{E}\end{array}$ & $\begin{array}{l}33^{\circ} 63^{\prime} \mathrm{N} \\
33^{\circ} 93^{\prime} \mathrm{N}\end{array}$ & $\begin{array}{l}\text { Date palm + Citrus } \\
\text { Date palm + Citrus }\end{array}$ \\
\hline Salah AL-din & $\begin{array}{l}\text { Dujail } \\
\text { Balad }\end{array}$ & $\begin{array}{l}3 \\
2\end{array}$ & $\begin{array}{l}44^{\circ} 27^{\prime} \mathrm{E} \\
44^{\circ} 43^{\prime} \mathrm{E}\end{array}$ & $\begin{array}{l}33^{\circ} 81^{\prime} \mathrm{N} \\
34^{\circ} 59^{\prime} \mathrm{N}\end{array}$ & $\begin{array}{l}\text { Grape orchards } \\
\text { Grape orchards }\end{array}$ \\
\hline Babil & Al-Mahawil & 3 & $44^{\circ} 39^{\prime} \mathrm{E}$ & $32^{\circ} 84^{\prime} \mathrm{N}$ & Date palm \\
\hline Karbala & $\begin{array}{c}\text { Hindiya } \\
\text { Hussainia }\end{array}$ & $\begin{array}{l}3 \\
1\end{array}$ & $\begin{array}{l}44^{\circ} 19^{\prime} \mathrm{E} \\
44^{\circ} 06^{\prime} \mathrm{E}\end{array}$ & $\begin{array}{l}32^{\circ} 58^{\prime} \mathrm{N} \\
32^{\circ} 63^{\prime} \mathrm{N}\end{array}$ & $\begin{array}{c}\text { Date palm } \\
\text { Date palm + Citrus }\end{array}$ \\
\hline Amarah & $\begin{array}{l}\text { Amarah } \\
\text { Ali Algharbie } \\
\text { Kumayt }\end{array}$ & $\begin{array}{l}4 \\
3 \\
1\end{array}$ & $\begin{array}{l}47^{\circ} 14^{\prime} \mathrm{E} \\
46^{\circ} 69^{\prime} \mathrm{E} \\
46^{\circ} 94^{\prime} \mathrm{E}\end{array}$ & $\begin{array}{l}31^{\circ} 86^{\prime} \mathrm{N} \\
31^{\circ} 26^{\prime} \mathrm{N} \\
32^{\circ} 10^{\prime} \mathrm{N}\end{array}$ & $\begin{array}{l}\text { Date palm } \\
\text { Date palm } \\
\text { Wheat field }\end{array}$ \\
\hline Dhi Qar & $\begin{array}{l}\text { Nasrea-AL-jueber } \\
\text { Syd Dkhyl } \\
\text { Nasrea-AL- Mbader }\end{array}$ & $\begin{array}{l}4 \\
3 \\
2\end{array}$ & $\begin{array}{l}46^{\circ} 40^{\prime} \mathrm{E} \\
46^{\circ} 48^{\prime} \mathrm{E} \\
46^{\circ} 44^{\prime} \mathrm{E}\end{array}$ & $\begin{array}{l}30^{\circ} 59^{\prime} \mathrm{N} \\
31^{\circ} 13^{\prime} \mathrm{N} \\
31^{\circ} 15^{\prime} \mathrm{N}\end{array}$ & $\begin{array}{l}\text { Date palm } \\
\text { Date palm } \\
\text { Date palm }\end{array}$ \\
\hline Al-Qadisiyyah & Al Diwaniyah & 1 & $44^{\circ} 55^{\prime} \mathrm{E}$ & $31^{\circ} 59^{\prime} \mathrm{N}$ & Datepalm + Citrus \\
\hline Al-Muthanna & Samawah & 3 & $45^{\circ} 17^{\prime} \mathrm{E}$ & $31^{\circ} 19^{\prime} \mathrm{N}$ & Date palm + Citrus \\
\hline Al-Basrah & $\begin{array}{c}\text { Al-Qurnah } \\
\text { Al-Haritah } \\
\text { Shatt al-Arab } \\
\text { AL-Hota } \\
\text { Abu Al-Khaseeb } \\
\text { Nahar Khoz }\end{array}$ & $\begin{array}{l}3 \\
2 \\
4 \\
1 \\
5 \\
1\end{array}$ & $\begin{array}{l}47^{\circ} 47^{\prime} \mathrm{E} \\
47^{\circ} 74^{\prime} \mathrm{E} \\
47^{\circ} 77^{\prime} \mathrm{E} \\
47^{\circ} 78^{\prime} \mathrm{E} \\
47^{\circ} 88^{\prime} \mathrm{E} \\
47^{\circ} 93^{\prime} \mathrm{E}\end{array}$ & $\begin{array}{l}30^{\circ} 95^{\prime} \mathrm{N} \\
30^{\circ} 67^{\prime} \mathrm{N} \\
30^{\circ} 44^{\prime} \mathrm{N} \\
30^{\circ} 63^{\prime} \mathrm{N} \\
30^{\circ} 47^{\prime} \mathrm{N} \\
30^{\circ} 46^{\prime} \mathrm{N}\end{array}$ & $\begin{array}{c}\text { Date palm } \\
\text { Date palm } \\
\text { Date palm + Citrus } \\
\text { Date palm + Citrus } \\
\text { Date palm + Citrus } \\
\text { Date palm + Citrus }\end{array}$ \\
\hline Dohuk & Dohuk & 5 & $43^{\circ} 00^{\prime} \mathrm{E}$ & $36^{\circ} 52^{\prime} \mathrm{N}$ & Potato fields \\
\hline Sulaymaniyah & Sulaymaniyah & 5 & $45^{\circ} 26^{\prime} \mathrm{E}$ & $35^{\circ} 33^{\prime} \mathrm{N}$ & Potato fields \\
\hline Erbil & Erbil & 3 & $44^{\circ} 18^{\prime} \mathrm{E}$ & $35^{\circ} 70^{\prime} \mathrm{N}$ & Hills \\
\hline
\end{tabular}


Malformation features were determined according to wings normality, length, shape, colour, and in some cases the presence of wings; for instance, some adults were wingless and dead short time after emergence.

It can be seen from Table 4 that there were remarkable changes in the insect normal life cycle exemplified by reducing the duration of pupal stage that last from 9-12 days, in comparison with the control treatment which last 23-26 days. Most of the larvae transformed in pupae after 16 days from treatment at the isolate MARD 34; while, larvae from the isolate MARD 46 treatment turned to pupae after 19 days. Considerably, high number of the larvae and pupae were dead before reaching adult stage as illustrated in Table 4 through the reduction of survival percentage.

\section{Discussion and conclusions}

The present study emphasised that there was a significant effect of applying the two locally isolated entomopathogenic fungi $M$. anisopliae

Table 3. Malformed adults of $O$. agamemnon arabicus produced after treatment with the isolates MARD 46 and MARD34.

\begin{tabular}{lcccc} 
Days after treatment & \multicolumn{5}{c}{ Isolate MARD 34 } \\
& $1 \times 10^{5}$ & $\begin{array}{c}\text { Concentration } \\
1 \times 10^{7}\end{array}$ & $1 \times 10^{9}$ & $1 \times 10^{11}$ \\
20 Days & - & - & + & + \\
23 Days & + & ++ & ++ & ++ \\
\hline 27 Days & ++ & +++ & +++ & ++++
\end{tabular}

$\begin{array}{lcccc}20 \text { Days } & - & - & - & + \\ 23 \text { Days } & + & - & ++ & ++ \\ 27 \text { Days } & ++ & + & +++ & -\end{array}$

+ , low number and degree of malformed adults $(1) ;++$, moderate $(2-3) ;+++$, high $(4-6) ;++++$, the highest (6+); - , zero No. and $B$. bassiana recording a high level of reduction in survival percentage reaching $0.0 \%$ after 29 days of treatment. However, MARD 46 isolate (B. bassiana) inflected faster and higher reduction of longevity level among $O$. agamemnon arabicus larvae in comparison with the isolate MARD 34 (M. anisopliae). Ricaño et al. (2013) found that using more than one formula of $B$. bassiana can remarkably reduce survival and increase mortality rate among Red palm weevil larvae and adults. B. bassiana can increase mortality rate of Helicoverpa armigera larvae as well as mentioned by Agarwal (2012).

Most of the emerged adults from both isolate spore suspensions treatments revealed various degrees of severity of noticeable malformations particularly in wings. Nonetheless, higher number of malformed adults emerged after treating with MARD 34 isolate. This might be due to the shortening of some stage period 0 . agamemnon arabicus life cycle; for example the pupal stage lasts from 9-12 days in comparison with the control that last from 24-27 days. Hussein et al. (2013) demonstrated that treating Spodoptera littoralis (Boisd.) larvae with the entomopathogenic fungi Isaria fumosorosea (syn. Paecilomyces fumosoroseus) resulted in high number of malformed adults. Moreover, Sabbour and Abdel-Raheem (2014) found that exposing red palm wee-

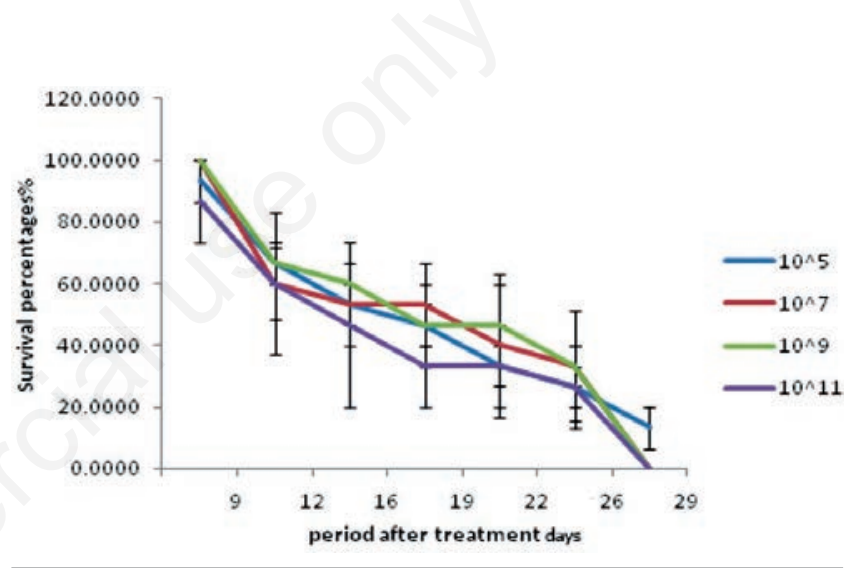

Figure 2. Survival percentages and error bar among date palm borer larvae $O$. agamemnon arabicus treated with the $M$. anisopliae isolate MARD34 four spore suspension concentrations.

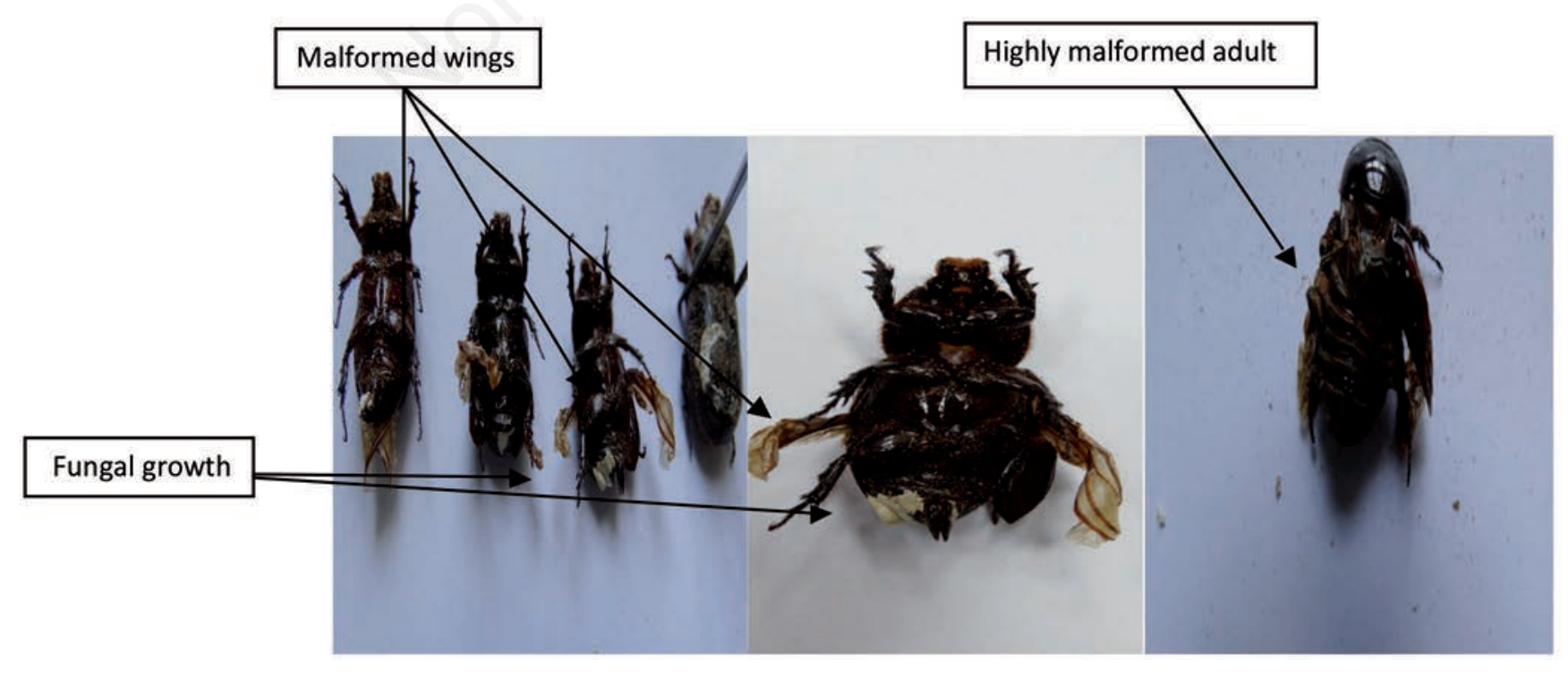

Figure 3. Malformed adults from both isolates MARD 34 and MARD 46. 
Table 4. Changes in date palm borers' O. agamemnon arabicus life cycle after treating them with MARD 34 and 46 spore suspensions concentration.

\begin{tabular}{|c|c|c|c|c|c|}
\hline $\begin{array}{l}\text { Spore suspension } \\
\text { Concentrations }\end{array}$ & \multicolumn{5}{|c|}{ MARD 46 isolate } \\
\hline $1 \times 10^{5}$ & 100\% Larvae & 46.6\% Pupa & 40\% Pupa & 26.3\% Adults + 13.3\% Pupa & 100\% Dead \\
\hline $1 \times 10^{7}$ & 100\% Larvae & 26.6\% Pupa & 40\% Pupa & $13.3 \%$ Adults & 93.3\% Dead \\
\hline $1 \times 10^{9}$ & 100\% Larvae & 33.3\% Pupa & $33.3 \%$ Pupa & $33.33 \%$ Adults & $100 \%$ Dead \\
\hline $1 \times 10^{11}$ & 6.6\% Pupa & 13.3\% Pupa & 6.6\% Pupa & 6.6\% Pupa & 100\% Dead \\
\hline Control & 100\% Larvae & 100\% Larvae & 40.6\% Pupa & 86.6\% Pupa & 100\% Pupa \\
\hline \multicolumn{6}{|c|}{ MARD 34 isolate } \\
\hline $1 \times 10^{5}$ & 40\% Pupa & $33.3 \%$ Pupa & $26.6 \%$ Pupa & $13.3 \%$ Pupa+ $6.6 \%$ Adults & $13.3 \%$ Adults $+6.6 \%$ Dead adults \\
\hline $1 \times 10^{7}$ & $60 \%$ Pupa & 46.6\% Pupa & $33.3 \%$ Pupa & $26.6 \%$ Adults & $100 \%$ Dead adults \\
\hline $1 \times 10^{9}$ & 46.6\% Pupa & 46.6\% Pupa & 46.6\% Pupa & $26.6 \%$ Adults $+6.6 \%$ Pupa & $100 \%$ Dead adults \\
\hline $1 \times 10^{11}$ & $33.3 \%$ Pupa & $33.3 \%$ Pupa & $33.3 \%$ Pupa & 33.3 Adults & 100\% Dead \\
\hline Control & 100\% Larvae & 100\% Larvae & $40.6 \%$ Pupa & $86.6 \%$ Pupa & $100 \%$ Pupa \\
\hline
\end{tabular}

vil Rhynchophorus ferrugineus to Isaria fumosorosea isolates can cause high level of malformation among pupae.

Other recorded results were the significant change in date palm borer life cycle exemplified by the reduction of pupal and larval period in comparison with the control. Rahman et al. (2010) reported that exposing Ostrinia nubilalis to the combination of $B$. bassiana and Nosema pyrausta resulted in shorter lifecycle, and females oviposited fewer eggs in comparison with the non-exposed insects. Gindin et al. (2006) stated that treating red palm weevil Rhynchophorus ferrugineus with different formulations of $M$. anisopliae and B. bassiana can make oviposition period shorter and decrease females fertility.

\section{References}

ABDULLAH S.K., LORCA L.L., JANSSON H., 2010 - Diseases of date palms (Phoenix dactylifera L.). - Basrah J. for Date Palm Res. 9: 40.

ABUL-SOAD A.A., MAITLO W.A., MARKHAND G., MAHDI S.M., 2011 Date palm wilt disease (sudden decline syndrome) in Pakistan, symptoms and remedy. - The Blessed Tree 3: 38-43.

AGARWAL R., 2012 - Biopesticidal formulation of Beauveria Bassiana Effective against Larvae of Helicoverpa Armigera. - J. Biofertil. Biopest. 3: 1-3.

AL-DEEB M.A., BIN M.S., MOHAMMAD S.E., 2012 - Interactions between Phoretic Mites and the Arabian rhinoceros beetle, Oryctes agamemnon arabicus. - J. Insect Sci. 12: 1-14.

BEDFORD G.0., 1980 - Biology, ecology, and control of palm rhinoceros beetles. - Ann. Rev. Entomol. 25: 309-339.

DHIAB I.M., SWAYIR I.A., ABDUL-HADI I., 1979 - Investigation on palm stem borer Pseudophilus testasceus Gah. (Coleoptera: Cerambycidae). - Yearbook Plant Prot. 2: 103-112.

ELWAN A.S., AL-TAMEIMI S.S., 1999 - Survey of the insect and mite pests as associated with date palm trees in Al- Dakhliya region. Egypt. J. Agric. 78: 653-654.

F.A.0., 1982 - Date production and protection: with special reference to North Africa and the Near East. - Food and Agriculture Organization, Rome: 35.

GINDIN G., LEVSKI S., GLAZER I., SOROKER V., 2006 - Evaluation of the entomopathogenic fungi Metarhizium anisopliae and Beauveria bassiana against the red palm weevil Rhynchophorus ferrugineus. Phytoparasitica. 34: 370-379.

HUSSAIN A.A., 1974 - Date palms \& dates with their pests in Iraq, Baghdad. - University of Baghdad: 166 pp.

HUSSEIN H., ZEMEK R., HABUŠTOVÁ S., PRENEROVÁ E., ADEL M.M., 2013 - Laboratory evaluation of a new strain CCM 8367 of Isaria fumosorosea (syn. Paecilomyces fumosoroseus) on Spodoptera littoralis (Boisd.). - Archiv. Phytopathol. Plant Prot. 46: 1307-1319.

IHARA F., YAGINUMA K., KOBAYASHI N., MISHIRO K., TAKERU S., 2001 - Screening of entomopathogenic fungi against the brown-winged green bug, Plautia stali Scott (Hemiptera: Pentatomidae). - Appl. Entomol. Zool. 36: 495-500.

JONASON N.B., BOETEL M.A., EIDE J.D., CAMPBELL L.G., RAO MAREPALLI B., 2005 - Virulence of Metarhizium anisopliae (Deuteromycotina: Hyphomycetes) to Sugarbeet Root Maggot (Diptera: Ulidiidae) larvae. - J. Sugar Beet Res. 42: 103-117.

KHUDHAIR M.W., ALRUBEAI H.F., KHALAF M.Z., SHBAR A.K., HAMAD B.S., KHALAF H.S., 2014 - Occurrence and distribution of entomopathogenic fungi in Iraqi agro-ecosystems. - Int. J. Entomol. Res. 2: 117-124.

LIU S.D., LIN S.C., SHIAU J.F., 1989 - Microbial control of coconut leaf beetle (Brontispa longissima) with green muscardine fungus, Metarhizium anisopliae var. anisopliae. - J. Invertebr. Pathol. 53: 307-314.

MILNER R.J., SOPER R.S., 1981 - Bioassay of Entomophthora against the spotted alfalfa aphid Therioaphis trifolii f. maculata. - J. Invertebr. Pathol. 37: 168-173.

MOORHOUSE E.R., GILLESPIE A.T., CHARNLEY A.K., 1993 - Laboratory selection of Metarhizium spp. isolates for control of vine weevil larvae (Otiorhynchus sulcatus). - J. Invertebr. Pathol. 62: 15-21.

PUTERKA G.J., HUMBER R.A., POPRAWSKI T.J., 1994 - Virulence of fungal pathogens (Imperfect Fungi: Hyphomycetes) to Pear psylla (Homoptera: Psyllidae). - Environ. Entomol. 23: 514-520.

RAGOUSSIS V., GIANNIKOPOULOS A., SKOKA E., GRIVAS P., 2007 Efficient synthesis of ( \pm )-4-methyloctanoic acid, aggregation pheromone of rhinoceros beetles of the genus Oryctes (Coleoptera: Dynastidae, Scarabaeidae). - J. Agric. Food Chem. 55: 5050-5052.

RAHMAN K.M.A., BARTA M., CAGÁŇ L., 2010 - Effects of combining Beauveria bassiana and Nosema pyrausta on the mortality of Ostrinia nubilalis. - Cent. Eur. J. Biol. 5: 472-480. 
RICAÑO J., GÜERRI-AGULLÓ B., SERNA-SARRIÁS M.J., RUBIO-LLORCA G., ASENSIO L., BARRANCO P., LOPEZ-LLORCA L.V., 2013 - Evaluation of the pathogenicity of multiple isolates of Beauveria bassiana (Hypocreales: Clavicipitaceae) on Rhynchophorus ferrugineus (Coleoptera: Dryophthoridae) for the assessment of a solid formulation under simulated field conditions. - Fla. Entomol. 96: 1311-1324.

ROCHAT D., MOHAMMADPOOR K., MALOSSE C., AVAND-FAGHIH A., LETTERE M., BEAUHAIRE J., MORIN J.-P., PEZIER A., RENOU M., ABDOLLAHI G.A., 2004 - Male aggregation pheromone of date palm fruit stalk borer Oryctes elegans. - J. Chem. Ecol. 30: 387-407.

SABBOUR M., ABDEL-RAHEEM M., 2014 - Evaluations of Isaria fumosorosea isolates against the Red Palm Weevil Rhynchophorus ferrugineus under laboratory and field conditions. - Curr. Sci. Int. 2077-4435.
SAMUELS K.D.Z., HEALE J.B., LLEWELLY M., 1989 - Characteristics relating to the pathogenicity of Metarhizium anisopliae toward Nilaparvata lugens. - J. Invertebr. Pathol. 53: 25-31.

SCOTT J.B., CHAKRABORTY S., 2010 - Genotypic diversity in Fusarium pseudograminearum populations in Australian wheat fields. - Plant Pathol. 59: 338-347.

SOLTANI R., 2010 - The rhinoceros beetle Oryctes agamemnon arabicus in Tunisia: current challenge and future management perspectives. - Tunisian J. Plant Prot. 5: 179-193.

SOLTANI R., 2012 - Laboratory rearing of immature stages of Oryctes agamemnon arabicus under three constant temperatures. Tunisian J. Plant Prot. 7: 35-43.

ZIMMERMANN G., 1986 - The 'Galleria bait method' for detection of entomopathogenic fungi in soil. - J. Appl. Entomol. 102: 213-215. 